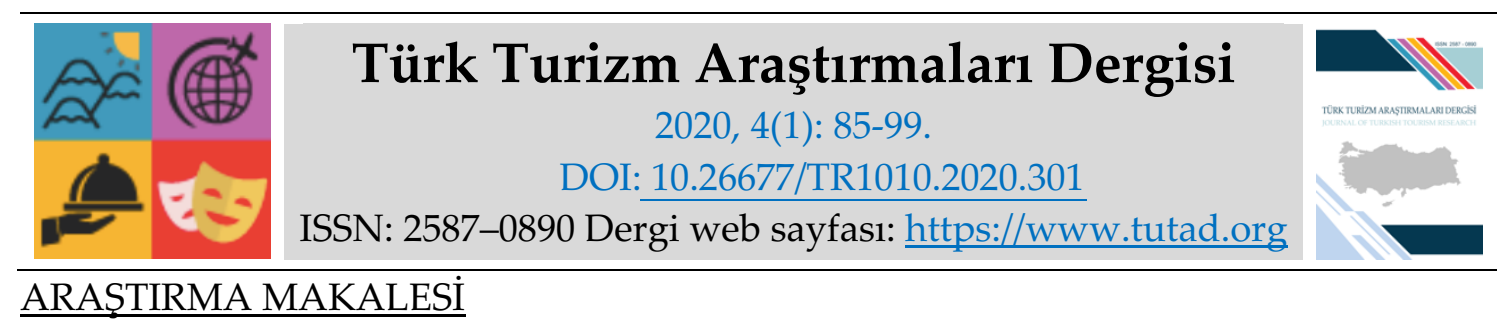

\title{
Aşçıların Tükenmişlik Düzeylerinin Belirlenmesine Yönelik Kars İlinde Bir Araştırma
}

Dr. Öğr. Üyesi Serkan NAKTIYYK, Kafkas Üniversitesi, İktisadi ve İdari Bilimler Fakültesi, Kars, e-posta: snaktiyok@kafkas.edu.tr ORCID: https://orcid.org/0000-0003-1226-2940

Erman KAYGIN, İşletme Bilim Uzmanı, Kafkas Üniversitesi, Sosyal Bilimler Enstitüsü, Kars, eposta: ermankaygin25@hotmail.com ORCID: https://orcid.org/0000-0002-0766-7575

Ethem TOPÇUOĞLU, Doktora Öğrencisi, Kafkas Üniversitesi, Sosyal Bilimler Enstitüsü, Kars, eposta: ethemtopcuoglu@kafkas.edu.tr ORCID: https://orcid.org/0000-0003-3563-0566

Öz

Aşçılık mesleği, aynı tadın sağlanması ve işletmenin devamlılığı açısından önemli bir sanat dalıdır. Tükenmişlik kavramı aşçıların performansını düşüren onların yapacakları işlerden uzaklaşmasına neden olan ve verimliliği azaltan bir kavramdır. Yapılan çalışmada yoğun ve ağır şartlar altında çalışan aşçıların tükenmişlik düzeylerinin tespit edilmesi amaçlanmıştır. Öncelikle literatür taraması yapılarak aşçılar üzerine böyle bir çalışmanın daha önce yapılmadığı tespit edilerek literatüre katkı sağlamak maksadıyla bu çalışma gerçekleştirilmiştir. Kars ilinde bulunan 127 aşçıya uygulanan Maslach Tükenmişlik Anketi sonucunda elde edilen veriler ışığında aşçıların tükenmişlik düzeylerinin tespiti sağlanmıştır. Yapılan analiz sonucunda aşçılar arasında tükenmişlik alt boyutlarında cinsiyete, medeni hal, eğitim durumuna göre herhangi bir anlamlı farklılığın olmadığı belirlenmiş, deneyime, gelir durumuna ve yaşa göre ise tükenmişlik düzeylerinde kısmen anlamlı farklılıkların olduğu tespit edilmiştir. Araştırmaya katılan aşçların duygusal tükenme alt boyutunda ortalamasının ( $\overline{\mathrm{x}}: 1.54)$, duyarsızlaşma alt boyutunda ortalamasının $(\bar{x}: 1,59)$ ve kişisel başarı alt boyutunda ortalamasının $(\overline{\mathrm{x}}: 2,04)$ olduğu belirlenmiştir. Bunların bir sonucu olarak aşçların düşük düzeyde tükenmişlik yaşadığı belirlenmiştir.

Anahtar Kelimeler: Aşçılık, Tükenmişlik, Aşçların Tükenmişlik Düzeyi, Kars.

Makale Gönderme Tarihi: 23.10.2019

Makale Kabul Tarihi: 09.01.2020

Önerilen Atıf:

Naktiyok, S., Kaygın, E. ve Topçuoğlu, E. (2020). Aşçların Tükenmişlik Düzeylerinin Belirlenmesine Yönelik Kars İlinde Bir Araştırma, Türk Turizm Araştırmaları Dergisi, 4(1): 85-99. (C) 2020 Türk Turizm Araştırmaları Dergisi. 


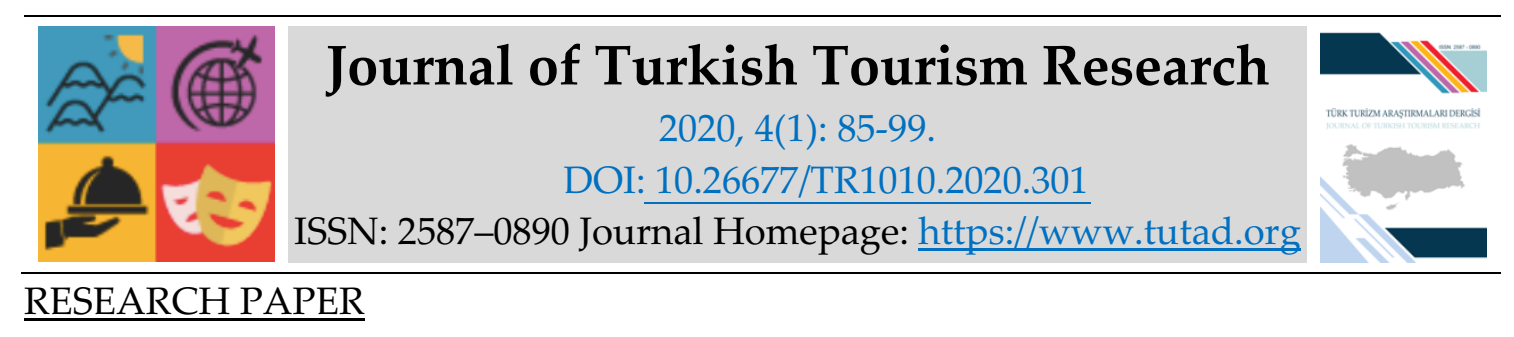

\title{
A Research on Determination of Burnout Levels of Cookery in Kars Province
}

Assistant Prof. Dr. Serkan NAKTIYOK, Kafkas University, Faculty of Economics and Administrative Sciences, Kars, e-mail:snaktiyok@kafkas.edu.tr

ORCID: https://orcid.org/0000-0003-1226-2940

Erman KAYGIN, MSc., Kafkas University, Social Sciences Institute, Kars, e-mail: ermankaygin25@hotmail.com

ORCID: https://orcid.org/0000-0002-0766-7575

Ethem TOPÇUOĞLU, PhD. Student, Kafkas University, Social Sciences Institute, Kars, e-mail: ethemtopcuoglu@kafkas.edu.tr

ORCID: https://orcid.org/0000-0003-3563-0566

\begin{abstract}
The cookery profession is an important branch of art in terms of providing the same taste and continuity of the business. The concept of burnout is a concept that reduces the performance of the cooks, causes them to move away from their work and reduces the productivity. In this study, it was aimed to determine the burnout levels of cooks working under heavy and heavy conditions. Firstly, the literature review was conducted and it was determined that such a study on cooks had not been done before and this study was carried out in order to contribute to the literature. In the light of the data obtained from Maslach Burnout Inventory applied to 127 cooks in Kars province, burnout levels of cookery were determined. As a result of the analysis, it was found that there was no significant difference between the chefs in terms of burnout subdimensions according to gender, marital status, education level and partially significant differences in burnout levels according to experience, income and age. It was found that the average of the cookery participating in the study was in the emotional exhaustion sub-dimension (x: 1.54), the average in the depersonalization sub-dimension (x: 1.59) and the average in the personal achievement sub-dimension ( $\bar{x}: 2.04)$. As a result, it was determined that the cookery experienced low levels of burnout.
\end{abstract}

Keywords: Cookery, Burnout, Burnout Level of Cooks, Kars.

Received: 23.10 .2019

Accepted: 09.01.2020

Suggested Citation:

Naktiyok, S., Kaygın, E. and Topçuoğlu, E. (2020). A Research on Determination of Burnout Levels of Cookery in Kars Province, Journal of Turkish Tourism Research, 4(1): 85-99.

(c) 2020 Türk Turizm Araştırmaları Dergisi. 


\section{Gíriş}

İnsanların yeni yerler ve tatlar keşfetme isteğine paralel olarak turizm sektörü ülkemizde ve dünyada hızla büyümeye devam etmektedir. 2018 yılında Türkiye'ye gelen turist sayısı bir önceki yıla göre \%21,42 büyüme ile 38 milyon 951 bin kişi olarak gerçekleşmiş ve 24 milyar dolar harcama yapılmıştır (TÜIK, 2019). Turizm sektörünün temel faaliyet alanı, herhangi bir nedenle daimi ikametgâhından geçici süreliğine ayrılmış bireylerin konaklama ve seyahat gereksinimlerini karşılamaya yönelik ürünleri sunan işletmeleri kapsamaktadır (Serin Karacaer ve Öztürk, 2019:245). Türkiye'de deniz, kum ve güneş şeklinde kendini gösteren kıyı turizminin yanı sıra gastronomi, inanç, dağcılık, termal ve sağlık, kış, kongre turizmi gibi birçok alternatif turizm çeşitleri de bulunmaktadır. Ülkemize yönelik turizm talebinde sürekli bir artışın olduğu görülmekte olup alternatif turizm çeşitleri sayesinde turizm faaliyetinin bütün bir yıla yayılmaya çalışıldığ1 tespit edilmiştir. Yapılan çalışmalar neticesinde sürdürülebilir turizm yaklaşımının benimsenmesi ve rekabet üstünlüğünün sağlanması açısından alternatif turizm alanlarına yatırımların artarak devam ettiği belirlenmiştir (Çelik Uğuz, 2011: 332). Gastronomi turizmi bu açıdan büyük önem taşımaktadır. Gastronomi Turizmi Derneği (2018) tarafından günümüzde dünya turizmindeki harcamalar incelendiğinde, tatile çıkan turistlerin temel harcamalarının \%28'sini yeme içme gereksinimlerine harcadıkları gözükmektedir. Ancak gastronomi turizmi içerisinde seyahatlerini gerçekleştiren turistlerin temel yeme içme harcamaları \%35 olarak gerçekleşmektedir (Kemer, 2019: 283).

Günümüzde yeme ve içme faaliyeti tüm toplumlarda önemli bir yer tutmaktadır. Yeme ve içme faaliyeti tarihin ilk dönemlerinde temel ihtiyaçların giderilmesine yönelik iken zamanla sosyal, kültürel ve statüsel bir simge haline gelmiştir. Bu faaliyet aile, dostluk ve arkadaşlık bağlarını güçlendirmek için yapılan yemek, kokteyl ve ziyaretlerde karşımıza çıkmaktadır. Örneğin Türk kahvesi ikramı ve kırk yıl hatırının olması bu etkinliklerin önemini temsil etmektedir (Harbalığlu ve Ünal, 2014: 61). Yemeğin insanların hayatında yer alan önemine uygun olarakta aşçılık mesleğine olan ilgi artmaktadır. Aşçlık sadece var olan mevcut malzeme ile yemek yapmanın ötesinde gıda maddelerinin tarla veya hasat sürecinden başlayarak, seçilmesini, satın alınmasını, teslim alınmasını, depolanması ve saklanmasını ve en uygun zamanda nihai ürün olarak müşteriye sunulması aşamalarından var olan bir sanat dalı olarak da kabul edilmektedir (Kurnaz vd., 2014: 43).

Aşçllık, günümüzde sadece standart yemek reçeteleri ve pişirme tekniklerini uygulamasından ibaret olmayıp sürdürülebilir bir rekabetin sağlanması maksadıyla yemek reçeteleri ve pişirme tekniklerini geliştirme çabasında bulunmaktadır. Bu çaba hem aşçların kişisel gelişimleri hem de içinde bulundukları örgütlerin gelişimi için önem arz etmektedir. Sanat, bilim ve kültür bileşenlerinin bir harmanını oluşturan aşçlar yemeğe girecek malzemenin temininden, saklanması, hazırlanması, pişirilmesi, tüketimi ve müşteri geri dönüşlerinin alınması aşamalarında aktif bir şekilde yer almaktadır (Horng ve Hu, 2008: 225). Aşçıların birçok alanda yer alması sonucunda yaşanan olumsuzluklar işletmelere anında yansımakta olup olumsuzlukların sonucunda işletmeler gelir ve müşteri kaybı ile karşılaşmaktadır. Aşçıların yaşadığı olumsuzluklardan birini tükenmişlik sendromu oluşturmaktadır.

\section{KAVRAMSAL ÇERCEVE}

Aşçlık gözde ve istenilen bir meslek olmasıyla beraber bazı olumsuz yönleri de bulunmaktadır. Müşteri isteklerinin anlık olarak alınması ve hızlı bir şekilde hazırlanması gerekliliği bulunmaktadır. Ayrıca yapılan yemeğin niteliği müşterinin o andaki ruh durumu ve açlı̆̆ına bağlı olarak değişmektedir. Birçok otel ve işletmenin sadece yaz aylarında veya sadece kış 
aylarında çalışması nedeniyle sektörde mevsimsel istihdam olanakları bulunmaktadır. Bu ve benzeri nedenler aşçllık mesleği için bir stresör olup bireysel tükenmişliğe sebebiyet vererek kişilerin performansını ve hayatını etkilemektedir. Bu etkinin bir yansıması olarak işletmelerde verimlilik düşmekte ve kalite azalmaktadır (Na vd., 2009: 575). Bu nedenle aşçların tükenmişlik düzeylerinin belirlenmesi işletmelerin karlılı̆̆ ve etkinliği açısından önemli bir unsurdur.

Kavramsal çerçeve, aşçılık mesleğinin önemini ve ülkemizde oluşan ilginin sebeplerinin açılanması, tükenmişlik kavramının yerli ve yabancı bilim insanlarının görüşlerinden istifade ile tanımlanması ile ülkemizde turizm alanında yapılan tükenmişlik konusunda çalışmalarını kapsayacak şekilde hazırlanmıştır.

\section{Aş̧̧ıllık Mesleği}

Günümüzde aşçılık mesleği Ahilik Teşkilatından beri devam eden usta çırak ilişkisi dışında mesleki eğitim kurumlarının, meslek liselerinin, meslek yüksek okullarının ve fakültelerin bünyesinde bulunan bölümlerle beraber bilimsel bir yapıya bürünmüştür. Bu açıdan yeni yetişecek olan aşçıların bilgi ve becerilerinin ustalarının anlatma ve öğretme kabiliyeti, mesleki yeteneği, baskıcı uygulamaları ile sinırlandırılmasının önünde bulunan engel kaldırılarak aşçıların farklı yerlerde staj yapması ve uygulamalı eğitim alması sağlanmıştır (Hughes, 2003: 10).

Ülkemizde kişiler açısından aşçılık talep gören ve istenen bir meslek dalı haline gelmiştir. Kolay iş bulunabilmesi, maaşların iş yerine göre farklılık gösterse de piyasa koşullarına göre yüksek olması, insanların sevdiği işi yapması ve insanların beğeni ve taleplerine açık olarak gelişime imkân vermesi sebebiyle aşçllık, gastronomi ve mutfak sanatları tercih edilen bir meslek grubudur (Kurnaz, 2019: 613). Öğrencilerin üniversite eğitimi için yaptıkları tercihlerde bunu kanitlar niteliktedir. 2018 yılında ülkemizde (KKTC hariç) 40 üniversitede lisans eğitimi verilen Gastronomi ve Mutfak Sanatları Bölümü (Fakülte) kontenjanı 2.635 iken bu bölümü tercih eden öğrenci sayısı 101.725 kişi olmuştur (YÖK Atlas, 2018a). 2018 yılında ülkemizde (KKTC hariç) 68 üniversitede önlisans eğitimi verilen Aşçılık Bölümü kontenjanı 5.876 iken bu bölümü tercih eden öğrenci sayısı 83.690 kişi olmuştur (YÖK Atlas, 2018b).

Ülkemizde ki bu büyük talebe karşıllk olarak mezun olan kişiler otel, uçak, gemi ve saygın lokantalarda çalışma hayatına başlamakta ve devam etmektedir. Tek bir kişiye veya birkaç kişiye hazırlanabilecek yemeklerin göz kararı tuz, baharat ve miktar hesaplaması yapılabilirken binlerce kişiye yapılan bir yemek için bu şekilde bir uyarlama mümkün değildir. Bu nedenle aşçılık mesleğinde kalitenin ve aynı tadın sağlanması maksadıyla reçeteler kullanılmaktadır. Reçete doktorun hastasına yazdığı iyileşme yönteminde olduğu gibi yemeğin içine katılacak malzemeden pişirme tekniğine kadar bütün unsurları açıklayan bir talimatlar bütününü oluşturmaktadır. Reçeteler daha önceki deneyim ve tecrübelere dayanmaktadır. Reçetelere rağmen aşçların yaptığı yemeklerin lezzetlerinde küçük farklılıkların bulunduğu görülmektedir. Yapılan yemeklerde bu farklılığın çeşitli sebepleri olmak ile beraber bunlardan birinin tükenmişlik olduğu düşünülmektedir.

\section{Tükenmişlik Kavramı}

İnsanların işi ve çalışma ortamı ile olan ilişkileri ve bu ilişki bozulduğunda ortaya çıkabilecek zorluklar, uzun zamandır modern çağın önemli bir olgusu olarak kabul edilmektedir. Tükenmişlik terimi, 1970'lerde, özellikle hizmet sektöründe çalışan insanlar arasında, bir miktar düzensizlik ile ortaya çıkmaya başlamıştır. Tükenmişlik kavramının, Greene'in 1961 yılında 
yazdığı A Burn-Out Case (Bir Tükenmişlik Hadisesi) romanıyla birlikte popülerlik kazanarak kullanımını yaygınlaşmıştır. Bu romanda işi nedeniyle eziyet çeken ve hayal kırıklığına uğramış bir mimarın her şeyi geride bırakarak Afrika ormanlarında yaşamaya başladığı anlatılmaktadır. Bu romandan öncede tükenmişlik adı konulmasa da birçok yazar tarafından hem kurgusal hem de kurgusal olmayan şekliyle kişilerin aşırı yorgunluk, bitkinlik, usanmışlık, kişinin işi için idealizm ve tutku kaybı gibi benzer olaylar ile tanımlamıştır (Maslach vd., 2001: 399).

Freudenberger (1974: 159) tarafından tükenmişliğin nedeni çalışanları başarıya ve harekete geçiren içsel kaynaklarında oluşan bitkinlik ve isteksizlik hissinin varlığı olarak tanımlanmıştır. Bunun bir sonucu olarak kişilerde fizyolojik bitkinlik, yorgunluk, duygusal dengesizlik, ağrı hissi, nefes almada güçlükler, sindirim sistemi rahatsızlıkları, engellenme duygusuna kapılma şeklinde belirtiler tespit edilmiştir.

Edelwich ve Brodsky (1980) tarafından tükenmişliğin, çalışanların örgütsel koşullarının iyi olmaması, müşteri yoğunluğunun fazla olması veya hiç olmaması, çalışanların ücretlerinin düşük olması, iş yerinde bürokratik ve politik baskıların bulunması, uzun çalışma saatlerinin bulunması gibi nedenler sonucu ortaya çıtığı belirlenmiştir. Ayrıca yüksek idealler ile ulaşılabilen nokta arasındaki farklılıktan kaynaklanan enerji kaybı ve amacın yitirilmesiyle birlikte de tükenmişlik kendini göstermekte, ilerleyen süreçte bireyde büyük hayal kırıklıkları yaratmaktadir.

Cherniss (1980: 5) tarafından tükenmişliğin nedeni olarak çalışanların müşterilerle yoğun ve yakın ilişki kurması, iş yeri hedeflerinin belirsiz ve tanımsız olması, iş yerinde örgütsel desteğin zayıf olması, yönetim kademelerinde sorunların bulunması, işyerinde çalışanlar arasında rol belirsizlikleri ve çatışmalarının olması ve çalışanın kişilik özellikleri gösterilmektedir. Bu nedenlerin tamamının bir toplamı olarak kişinin beklentilerini karşılanamamasıyla birlikte oluşan stres, tükenmişliği ortaya çıkarmaktadır.

Maslach ve Jackson (1981:99)'e göre tükenmişlik kişinin kendini yorgun ve duygusal yönden aşırı yıpranmış hissetmesi ile ortaya çıkmaktadır. Tükenmişlik fiziksel yorgunluk ve bitkinlik hissi nedeniyle işten ve müşteriden soğuma, kendi kendinden şüphelenmeye varan ruhsal yorgunluk olarak devam ederek, herkesten uzaklaşmaya neden olmaktadır.

Pearlman ve Hartman (1982), Meier (1983) ile Golembiewski ve arkadaşlarına (1983) göre tükenmişlik iş yerinde sürekli devam eden stres ya da baskı sonucu ortaya çıkmaktadır. Kişilerde bunun bir sonucu olarak kronik, fiziksel, duygusal ve zihinsel yıpranma görülmektedir.

Cordes ve Daugherty (1993: 621)'e göre tükenmişlik, duygusal tükenme, duyarsızlaşma ve azalmış kişisel başarı ile karakterize edilmiş eşsiz bir stres sendromudur. Araştırmalar sonucunda hemşirelik, eğitim ve sosyal hizmet gibi yardımcı meslek gruplarında tükenmişlik sık rastlanan bir sendrom olup işletmelerde çok ciddi ekonomik zararlara neden olmaktadır.

Maslach ve arkadaşlarına (2001: 399) göre tükenmişlik, kişilerin sinirli olmasına, performans azalış ve kayıplarına, yaptıkları işlerde kalite ve niteliklerin azalmasına, kendilerini önemsiz ve değersiz hissetmeleri ile ilişki içinde bulunduğu iş ve kişilere karşı duyarsız kalmasına sebebiyet vermektedir.

Avşaroğlu ve arkadaşlarına (2005: 106) göre tükenmişlik, kişinin iç dünyasında ortaya çıkan, bireylerin tutumları, beklentileri ve algılarına göre oluşan psikolojik bir deneyim ve yapılan işle alakalı kronik stresin bir ürünüdür.

Güllüce ve İşcan (2010: 8)'a göre tükenmişlik, yapılan iş veya iş ortamında kişilerin sorunlu ve problemli olması sonucunda bireylerde oluşan ve kronikleşen bir gerginliğe karşı oluşan bir tepkidir. Tükenmişlik hemşirelik, hekimlik, polislik ve öğretmenlik gibi sorunlu ve problemli 
işler ile uğraşan meslek dallarında ağırlıklı olarak görülmektedir. Ayrıca tükenmişlik strese benzer belirti ve etkiler göstermesi nedeniyle bir stres türü olarakta değerlendirilmektedir.

Yıldırım (2018: 303)'a göre tükenmişlik, işletmelerde çalışan kişilerin daha çok duygusal çaba ve emek harcamasını gerektiren durumlara maruz kalması neticesinde ortaya çıkan fiziksel, zihinsel ve duygusal tükenme halidir. İş hayatının her geçen gün daha stresli bir hal aldığı günümüzde tükenmişlik sık rastlanılan bir durum olup en sade biçimi ile kişinin psikolojik ve fiziksel olarak çökmesi durumudur.

Yapılan tanımlamalardan anlaşılacağı üzere tükenmişlik, stres sonucu ortaya çıan, kişilerin ruh dünyasını etkisi altına alarak insanlardan ve işten uzaklaşmasına neden olan, fiziksel ve psikolojik yansımaları bulunan bir hastalıktır. Tükenmişlik, işe kendini verememe, hatalı üretim, iş yeri devamsızlıkları, işe geç gelme, işten ayrılma gibi sonuçları sebebiyle işletmelerde büyük ekonomik zararlara neden olmaktadır. Aşçılık mesleğinde tükenmişlik, büro memurunun rakamları veya tutarları yanlış girmesinden farklı olarak kesik, yaralanma ve yanık oluşması gibi tehlikeli ve ölümcül sonuçlar doğurmaktadır.

\section{Tükenmişlik Hakkında Yapılan Çalışmalar}

Tükenmişlik ile ilgili ilk çalışmalar bir alternatif sağllk tedavi merkezinde psikiyatrist olarak çalışan Freudenberger (1974) ve iş hayatındaki duyguları inceleyen sosyal psikolog Maslach (1976) tarafından yapılmıştır (Maslach vd., 2001: 399). Ülkemizde ise ilk çalışmalar Ergin (1992) tarafından yapılmıştır.

Ergin (1992) tarafından ülkemizde doktorlar ve hemşireler üzerine yapılan çalışmanın sonrasında hastane yöneticileri, polisler, öğretmenler, muhasebeciler, akademisyenler, öğrenciler ve otel çalışanları gibi geniş bir yelpazede birçok çalışma yapılmıştır. Literatürde sadece aşçılar üzerine yapılan bir tükenmişlik çalışılmasına rastlanılmamıştır. Bu kapsamda aş̧̧ılarında araştırmaya katıldığı düşünülen turizm sektörü ve otel çalışanlarına ait ülkemizde yapılan bazı çalışmalar şunlardır.

Pelit ve Türkmen (2008) tarafından Maslach Tükenmişlik Ölçeği kullanılarak Ankara ve Antalya İlinde bulunan 5 yıldızlı 4 otelde çalışan 213 kişiye anket uygulanmıştır. Bu çalışmada T ve Anova testi yapılarak işgörenlerin cinsiyet, çalışılan otel, eğitim, çalışılan bölüm ve çalışma yılına göre tükenmişlik düzeylerinin tespiti yapılmıştır. Araştırma sonucunda çalışanların demografik özellikler bakımından birbirlerine yakın seviyede tükenmişlik yaşadıkları tespit edilmiştir.

Üngüren ve arkadaşları (2010) tarafından Maslach Tükenmişlik Ölçeği ile Hackman ve Oldham (1975) tarafından geliştirilen 14 maddelik iş tatmini ölçeği kullanılarak Antalya İlinde bulunan 4 otelde çalışan 181 kişiye anket uygulanmıştır. Bu çalışmada tükenmişlik alt boyutları ile iş tatmini arasındaki ilişki ve etkinin tespiti için Pearson korelasyon ve çoklu regresyon testleri yapılmıştır. Çalışmada uygulanan korelasyon analizi sonucunda iş tatminiyle duygusal tükenme ve duyarsızlaşma arasında negatif yönlü, kişisel başarı ile arasında ise pozitif yönlü bir ilişkinin olduğu belirlenmiştir.

Aslan ve Etyemez (2015) tarafından Maslach Tükenmişlik Ölçeği ile Carson ve arkadaşları (1999) tarafından geliştirilen 3 maddelik işten ayrılma niyeti ölçeği kullanılarak Hatay İlinde bulunan 15 otelde çalışan 200 kişiye anket uygulanmıştır. Bu çalışmada tükenmişlik alt boyutları ile işten ayrılma niyeti arasındaki ilişki ve etkinin tespiti için korelasyon ve regresyon testleri yapılmıştır. Çalışmada tükenmişlik alt boyutları ile işten ayrılma niyeti arasındaki ilişki belirlenmiş, her üç boyutun da işten ayrılma niyetini artırdığı ortaya çıkmıştır. 
Kaplan ve Ulutaş (2016) tarafından Maslach Tükenmişlik Ölçeği ile Pala ve Tepeci (2009) tarafından geliştirilen duygusal emek ölçeği 12 maddelik duygusal emek ölçeği kullanılarak Nevşehir İlinde bulunan 20 otelde çalışan 315 kişiye anket uygulanmıştır. Bu çalışmada tükenmişlik alt boyutları ile duygusal emek arasındaki etkinin tespiti için çoklu regresyon testleri yapılmıştır. Çalışmada uygulanan regresyon analizi sonuçlarına göre; duygusal emeğin derin davranış boyutunun tükenmişliğin duygusal tükenme ve duyarsızlaşma boyutları üzerinde negatif yönlü anlamlı, kişisel başarı hissi boyutu üzerinde ise pozitif yönlü ve anlamlı etkiye sahip olduğu tespit edilmiştir.

Güven ve Sezici (2016) tarafından Maslach Tükenmişlik Ölçeği kullanılarak Antalya İlinde bulunan 3,4 ve 5 yıldızlı 26 otelde çalışan 556 kişiye anket uygulanmıştır. Hipotez testi olan bu çalışmada ölçekte yer alan ifadelerin alt boyutlara dağılımı ve bu alt boyutların tükenmişliği ne ölçüde açıkladığı keşfedici ve doğrulayıcı faktör analizi ile test edilerek hipotezler denenmiştir.

Çetin (2018) tarafından Maslach Tükenmişlik Ölçeği kullanılarak Girne'de bulunan otellerde çalışan 171 kişiye anket uygulanmıştır. Bu çalışmada normal dağılım olmaması sebebiyle MannWhitney U ve Kruskall-Wallis-H testi yapılarak çalışanların cinsiyet, yaş, medeni durum, eğitim ve mesleki eğitim göre tükenmişlik düzeylerinin tespiti yapılmıştır. Araştırma sonucunda çalışanların cinsiyete ve eğitim durumuna göre kısmen, yaş, medeni durum ve mesleki eğitime göre anlamlı bir farklılığın bulunmadığı tespit edilmiştir.

Turizm sektöründe çalışanların tükenmişlik düzeyini belirlemek amacıyla yapılan çalışmalar yukarıya çıkarılmıştır. Yapılan incelenme sonucunda söz konusu çalışmaların bütün turizm çalışanlarını kapsadığı çalışmaların içerisinde aşçıların rolünün kapsamlı olarak belirlenmesinin mümkün olmadığı tespit edilmiştir. Turizm sektöründe çalışanların müşteriler ile birebir iletişim halinde olması, üretilen ürünlerin anlı olarak tüketilmesi, müşterinin ruh haline göre hizmet kalitesi ve niteliğinin değişmesi sonucunda çalışanların stres altında çalıştıkları görülmüştür. Bütün bu nedenler ile turizm çalışanlarının iş yerinde düşük düzeyde bir tükenmişlik yaşadığ belirlenmiştir.

\section{YÖNTEM}

Ülkemizde tükenmişlik konusunda yapılan çalışmalarda Maslach ve Jackson (1981) tarafından hazırlanan Maslach Tükenmişlik Ölçeğinin yaygınlığı sebebiyle araştırmada bu ölçek kullanılmıştır. Söz konusu ölçek 7'li Likert tipinde iken Ergin'in (1992) tarafından 5'li Likert tipinde Türkçeye çevrilmiş ve güvenirliği test edilerek bilim dünyasına kazandırılmıştır. Söz konusu ölçek duygusal tükenme, kişisel başarı ve duyarsızlaşma alt boyutlarından oluşmaktadır. Ölçek duygusal tükenme ( 9 madde), kişisel başarı (8 madde) ve duyarsızlık (5 madde) olmak üzere toplam 22 sorudan oluşmaktadır. Sorular 0 ile 4 (hiçbir zaman, çok nadir, bazen, çoğu zaman ve her zaman) arasında puanlanmış ve kişisel başarı soruları ters kodlanmıştır. Duygusal tükenme boyutu, tükenmişliğin bireysel ve stres boyutunu belirtmekte olup bireyin duygusal ve fiziksel kaynaklarında azalmayı ifade etmektedir (Budak ve Sürgevil, 2005: 96). Kişisel başarı boyutu, bireyin kendisine ilişkin değerlendirmelerinde genel bir olumsuzluk hissetmesi, işinde ilerleme kaydetmediğini, hatta gerilediğini, harcadığı çabanın bir işe yaramadığını ve çevresinde bir fark yaratmadığını düşünmesini kapsamaktadır. Duyarsızlaşma boyutu, kişinin kendinden ve işinden uzaklaşmasını, işe yönelik idealizmlerini ve coşkularını kaybetmesini, hizmet verilen kişilere karşı ilgisiz olmayı, olumsuz tutum ve davranışlarda bulunmayı tanımlamaktadır (Maslach vd., 2001: 403).

Araştırma Kars İli Merkez İlçesinde yapılmış olup evreni oluşturan toplam aşçı sayısının Esnaf ve Sanatkârlar Odası ile yapılan görüşme sonucunda 178 kişi olduğu belirlenmiştir. Belirtilen 
evrenin \%95 güven düzeyinde örneklem büyüklügü 122 olarak belirlenmiştir (https://www.surveysystem.com). Tükenmişlik anketi basit tesadüfî örneklem şeklinde araştırma evreninde bulunan aşçılara çalışma yerlerinde (lokanta, yurt ve catering) 01 Temmuz 2019 tarihi ile 05 Temmuz 2019 tarihleri arasında uygulanmıştır. Anket 141 aşçıya uygulanmış, 14 adet ankette eksik bilgi bulunması sebebiyle çalışmaya dâhil edilmeyerek 127 adet anketten elde edilen veriler ışığında araştırma verileri elde edilmiştir.

Araştırmadan elde edilen verilerin normal dağılıp dağılmadığını ölçmek için KolmogorovSmirnov ve Shapiro-Wilk testleri uygulanmıştır. Söz konusu testlere ilişkin basıklık ve çarpıklık değerleri $+1,5$ ile $-1,5$ arasında yer alması nedeniyle Denis (2019: 28)'e göre örneklem normal dağılmıştır.

Araştırmanın sorularına yönelik yapılan güvenilirlik analizinde Cronbach's Alpha değeri duygusal tükenme için 0.86, duyarsızlaşma için 0.80, kişisel başarı için 0.82 olarak tespit edilmiştir. Alpar (2013:849) 'a göre tespit edilen değerler yüksek güvenirliktedir. Benzer değerlerin polisler üzerinde Gündüz ve arkadaşları (2007: 286) tarafından yapılan araştırmada sırasıyla $0.83,0.63$ ve 0.80 olarak, Ulusoy ve arkadaşları (2012: 253) tarafından hastane yöneticileri üzerinde yapılan araştırmada sırasıyla 0.88, 0.64 ve 0.67 olarak, Kayan Fadlelmula (2014) tarafından akademisyenler üzerinde yapılan araştırmada sırasıyla 0.78 , 0.67 ve 0.73 olarak, Doğan ve Akandere (2019:156) tarafından Taekwondo antrenörleri üzerinde yapılan araştırmada sırasıyla $0.89,0.78$ ve 0.76 olarak tespit edildiği görülmüştür. Bu kapsamda tespit edilen değerlerin literatür ile uyumlu olduğu belirlenmiştir.

\section{BULGULAR VE TARTIŞMA}

Kars'ta faaliyet gösteren 127 aşçıdan uygulanan anket neticesinde elde edilen veriler ışığında SPSS programı ile T testi ve ANOVA testleri yapılarak sonuçlar aşağıya çıarılımıştır.

Araştırmaya katılan $82(\% 64,6)$ kişi erkek, $45(\% 35,4)$ kişi ise kadındır. Hair ve arkadaşlarına (2014:667) göre T testi aracıllğıyla yapılan ölçümün sonucunun $\mathrm{p}$ değerinin 0.05 'den küçük bir değere sahip olması anlamlı bir farklılı̆̆ın olduğunu göstermektedir. Ölçülen p değerinin 0.05 'den büyük olması nedeniyle tükenmişliğin cinsiyete göre anlamlı bir farklılık göstermediği tespit edilmiştir. Benzer sonuçların Cemaloğlu ve Erdemoğlu Şahin (2007: 472), Gündüz ve arkadaşları (2007:288), Ardınç ve Polatcı (2008: 87), Pelit ve Türkmen (2008: 131), Özgül ve Atan (2016:1008), Aknar ve arkadaşları (2018: 8), Yenihan ve arkadaşları (2018: 53) ile Doğan ve Akandere (2019:157) tarafından da elde edildiği görülmüştür. Çalışanların cinsiyetleri ile tükenmişlik alt boyutları arasında Çetin (2017: 93) tarafından sadece duygusal tükenme boyutunda, Üngüren ve arkadaşları (2010: 2931) tarafından duygusal tükenme, duyarsızlaşma boyutlarında, Şad ve Şahin (2018: 470) tarafından bütün alt boyutlarda anlamlı farklılık bulunmuştur. Bu kapsamda tespit edilen değerlerin literatür ile uyumlu olduğu belirlenmiştir.

Araştırmaya katılan $73(\% 57,5)$ kişi evli, 54 (\%42,5) kişi ise bekardır. Ölçülen p değerinin 0.05 'den büyük olması nedeniyle tükenmişliğin medeni duruma göre anlamlı bir farklılık göstermediği tespit edilmiştir. Medeni durum ile tükenmişlik arasında Budak ve Sürgevil (2005: 102), Metin ve Gök Özer (2007: 63), Özgül ve Atan (2016: 1008), Aknar ve arkadaşları (2018: 8), Şad ve Şahin (2018: 473) tarafından anlamlı farklılık bulunamamıştır. Ardınç ve Polatcı (2008: 81) tarafından kişisel başarı boyutunda, Cemaloğlu ve Erdemoğlu Şahin (2007: 472) ile Üngüren ve arkadaşları (2010: 2931) tarafından duygusal tükenme boyutunda, Çetin (2017: 90) tarafından duyarsızlaşma boyutunda anlamlı farklılık bulunmuştur. Bu kapsamda tespit edilen değerlerin literatür ile uyumlu olduğu belirlenmiştir. 
Tablo 1. Aşçıların Yaşa Göre Tükenmişlik Düzeyleri

\begin{tabular}{|c|c|c|c|c|c|c|}
\hline & & $\mathrm{N}$ & Ortalama & $\begin{array}{c}\text { Standart } \\
\text { Sapma }\end{array}$ & $\mathrm{F}$ & $\mathrm{p}$ \\
\hline \multirow{5}{*}{$\begin{array}{l}\text { Duygusal } \\
\text { tükenme }\end{array}$} & 20 ve altında & 17 & 1,5752 & 46851 & \multirow{5}{*}{890} & \multirow{5}{*}{,472 } \\
\hline & 21-30 yaş arası & 35 & 1,6381 & ,64132 & & \\
\hline & 31-40 yaş arası & 42 & 1,4603 & ,89482 & & \\
\hline & 41-50 yaş arası & 25 & 1,4133 & 90751 & & \\
\hline & 51yaş ve üzeri & 8 & 1,9028 & 39591 & & \\
\hline \multirow{5}{*}{ Duyarsızlaşma } & 20 ve altında & 17 & 1,6000 & 65574 & \multirow{5}{*}{4,374} & \multirow{5}{*}{,002 } \\
\hline & 21-30 yaş arası & 35 & 1,7029 & 60073 & & \\
\hline & $31-40$ yaş arası & 42 & 1,3667 & ,88557 & & \\
\hline & 41-50 yaş arası & 25 & 1,4720 & ,94495 & & \\
\hline & 51 yaş ve üzeri & 8 & 2,6000 & 78558 & & \\
\hline \multirow{5}{*}{ Kişisel başarı } & 20 ve altında & 17 & 2,1691 & 63882 & \multirow{5}{*}{1,637} & \multirow{5}{*}{, 169 } \\
\hline & $21-30$ yaş arası & 35 & 1,9893 & 70082 & & \\
\hline & $31-40$ yaş arası & 42 & 1,9673 & 69188 & & \\
\hline & $41-50$ yaş arası & 25 & 2,2700 & ,86277 & & \\
\hline & 51 yaş ve üzeri & 8 & 1,6250 & ,31339 & & \\
\hline
\end{tabular}

Araştırmaya katılan $17(\% 13,4)$ kişi 20 yaş ve altında, 35 (\%27,6) kişi 21 ile 30 yaş arasında, 42 $(\% 33,1)$ kişi 31 ile 40 yaş arasında, 25 (\%19,7) kişi 41 ile 50 yaş arasında ve $8(\% 6,3)$ kişi 51 yaş ve üzerinde bulunmaktadır. Yapılan Anova testi sonucunda ölçülen $p$ değerinin 0.05 'den büyük olması nedeniyle duygusal tükenme ve kişisel başarı boyutlarında anlamlı bir farklılık bulunamamıştır. Yaş ile duyarsızlaşma boyutu arasında bulunan anlamlı farklılığın Tukey testine göre bütün yaş kategorilerinde geçerliği olduğu belirlenmiştir. Çetin (2017: 93), Aknar ve arkadaşları (2018: 8-9) tarafından bütün boyutlarda, Ardınç ve Polatcı (2008: 81) kişisel başarı boyutunda, Cemaloğlu ve Erdemoğlu Şahin (2007: 472) tarafından duygusal tükenme ve duyarsızlaşma boyutunda anlamlı farklılık tespit edilmiştir. Özgül ve Atan (2016: 1007) tarafından anlamlı bir farklılık tespit edilememiştir. Bu kapsamda tespit edilen değerlerin literatür ile uyumlu olduğu belirlenmiştir.

Araştırmaya katılan 15 (\% 11,8) kişi 2.001 ile 3.000 Türk Lirasının altında, 35 (\% 27,6) kişi 3.001 ile 4.000 Türk Lirası arasında, 53 (\% 41,7) kişi 4.001 ile 5.000 Türk Lirası arasında, 16 (\% 12,6) kişi 4.001 ile 5.000 Türk Lirası arasında ve 8 (\% 6,3) kişi 6.001 Türk Lirası üzerinde ücret veya gelir elde etmektedir. Aylık gelir ile duygusal tükenme, duyarsızlaşma arasında ölçülen p değerinin 0.05'den büyük olması nedeniyle anlamlı bir ilişki bulunmazken kişisel başarı ile aylık gelir arasında anlamlı bir farklılık bulunmaktadır. Tespit edilen farklılık Tukey testine göre 6.001 TL ve üzerinde gelire sahip grup ile 3 grup (2.001-3.000 TL arasında, 3.001-4.000 TL arasinda gelire sahip grup, 5.001-6.000 TL arasında gelire sahip grup) arasında tespit edilmiştir.

Araştırmaya katılan 21 (\% 16,5) kişi lisans mezunu, 40 (\% 31,5) kişi önlisans, 24 (\% 18,9) kişi meslek lisesi mezunu, 18 (\% 14,2) kişi lise mezunu, 13 (\% 10,26) kişi ortaokul mezunu ve 11 (\% $8,7)$ kişi ilkokul mezunu olduğu tespit edilmiştir. Mezuniyet durumu ile tükenmişlik alt boyutları arasında ölçülen $p$ değerinin 0.05 'den büyük olması nedeniyle anlamlı bir ilişki bulunamamıştır. Doğan ve Akandere (2019:157) tarafından duygusal tükenmişlik ve kişisel başarı alt boyutlarında anlamlı farklılıklar tespit edilmiştir. Pelit ve Türkmen (2008:133) ile Aknar ve arkadaşları (2018:9) 
tarafından anlamlı bir farklılık tespit edilmemiştir. Bu kapsamda tespit edilen değerlerin literatür ile uyumlu olduğu belirlenmiştir. Bazı meslek grupları için zorunlu eğitim kıstasları ve mesleki giriş koşulları belirlenmiştir. Öğretmenlik gibi meslekleri tercih edenlerin en az lisans mezunu olması gibi zorunluluklar nedeniyle meslek gruplarının oluşumunun tek ve homojen bir grupta toplandığı görülmüştür. Bu nedenle eğitim düzeyine göre kişilerin tükenmişlik düzeyini araştıranların sayısının cinsiyet ve yaş gruplarına göre daha az olduğu görülmüştür.

Tablo 2. Aşçıların Gelire Göre Tükenmişlik Düzeyleri

\begin{tabular}{|c|c|c|c|c|c|c|}
\hline & & $\mathrm{N}$ & Ortalama & $\begin{array}{l}\text { Standart } \\
\text { Sapma }\end{array}$ & $\mathrm{F}$ & $\mathrm{p}$ \\
\hline \multirow{5}{*}{$\begin{array}{l}\text { Duygusal } \\
\text { tükenme }\end{array}$} & $\begin{array}{l}2001 \text { ile } 3000 \mathrm{TL} \\
\text { arasında }\end{array}$ & 15 & 1,5407 & ,44219 & \multirow{5}{*}{1,540} & \multirow{5}{*}{ 195 } \\
\hline & $\begin{array}{l}3001 \text { ile } 4000 \mathrm{TL} \\
\text { arasinda }\end{array}$ & 35 & 1,3651 & 72289 & & \\
\hline & $\begin{array}{l}4001 \text { ile } 5000 \mathrm{TL} \\
\text { arasinda }\end{array}$ & 53 & 1,6520 & 81418 & & \\
\hline & $\begin{array}{l}5001 \text { ile } 6000 \mathrm{TL} \\
\text { arasında }\end{array}$ & 16 & 1,7569 & ,79527 & & \\
\hline & 6001 TL ve üzerinde & 8 & 1,1806 & , 86869 & & \\
\hline \multirow{5}{*}{ Duyarsızlaşma } & $\begin{array}{l}2001 \text { ile } 3000 \mathrm{TL} \\
\text { arasında }\end{array}$ & 15 & 1,6800 & ,48873 & \multirow{5}{*}{0,879} & \multirow{5}{*}{,478 } \\
\hline & $\begin{array}{l}3001 \text { ile } 4000 \mathrm{TL} \\
\text { arasında }\end{array}$ & 35 & 1,4114 & 82597 & & \\
\hline & $\begin{array}{l}4001 \text { ile } 5000 \mathrm{TL} \\
\text { arasında }\end{array}$ & 53 & 1,6189 & ,94809 & & \\
\hline & $\begin{array}{l}5001 \text { ile } 6000 \mathrm{TL} \\
\text { arasında }\end{array}$ & 16 & 1,8500 & 73212 & & \\
\hline & 6001 TL ve üzerinde & 8 & 1,4750 & ,78513 & & \\
\hline \multirow{5}{*}{ Kişisel başarı } & $\begin{array}{l}2001 \text { ile } 3000 \mathrm{TL} \\
\text { arasında }\end{array}$ & 15 & 1,8417 & 82031 & \multirow{5}{*}{3,425} & \multirow{5}{*}{,011 } \\
\hline & $\begin{array}{l}3001 \text { ile } 4000 \mathrm{TL} \\
\text { arasında }\end{array}$ & 35 & 1,9000 & 68720 & & \\
\hline & $\begin{array}{l}4001 \text { ile } 5000 \mathrm{TL} \\
\text { arasında }\end{array}$ & 53 & 2,1250 & 66189 & & \\
\hline & $\begin{array}{l}5001 \text { ile } 6000 \mathrm{TL} \\
\text { arasında }\end{array}$ & 16 & 1,8672 & 63977 & & \\
\hline & 6001 TL ve üzerinde & 8 & 2,7813 & ,73421 & & \\
\hline
\end{tabular}

Araştırmaya katılan 13 (\% 10,2) kişi 2 yılın altında deneyime, $44(\%$ 34,6) kişi 2 yıldan 4 yıla kadar deneyime, 38 (\% 29,9) kişi 4 yıldan 8 yıla kadar deneyime, 18 (\% 14,2) kişi 8 yıldan 12 yıla kadar deneyime ve $14(\%$ 11,0) kişi 12 yıl ve üstünde deneyime sahiptir. Deneyim yılı ile duygusal tükenme, duyarsızlaşma arasında ölçülen p değerinin 0.05 'den büyük olması nedeniyle anlamlı bir ilişki bulunmazken kişisel başarı ile deneyim yılı arasında anlamlı bir farklılık bulunmaktadır. Tespit edilen anlamlı farklılık Tukey testine göre 8 yıldan 12 yıla kadar deneyime sahip grup ile 12 yıl ve üstünde deneyime sahip grup arasında tespit edilmiştir. Aknar ve arkadaşları (2018:11) tarafından çalışma süresi ile tükenmişlik davranışı arasında anlamlı bir farklılık tespit edilmiştir. 
Metin ve Gök Özer (2007: 63) tarafından çalışma yılları arttıkça duygusal tükenme ve duyarsızlaşma alt boyutunda tükenmişlik düzeyi azaldığı belirlenmiştir. Pelit ve Türkmen (2008: 134) ile Özgül ve Atan (2016: 1009) tarafından tükenmişlik boyutları arasında da anlamlı bir farklılık olmadığı tespit edilmiştir.

Tablo 3. Aş̧̧ıların Deneyimine Göre Tükenmişlik Düzeyleri

\begin{tabular}{|c|c|c|c|c|c|c|}
\hline & & $\mathrm{N}$ & Ortalama & $\begin{array}{l}\text { Standart } \\
\text { Sapma }\end{array}$ & $\mathrm{F}$ & $\mathrm{p}$ \\
\hline \multirow{5}{*}{$\begin{array}{l}\text { Duygusal } \\
\text { tükenme }\end{array}$} & 2 yıldan az & 13 & 1,8462 & 24653 & \multirow{5}{*}{1,689} & \multirow{5}{*}{0,157} \\
\hline & 2 yıldan 4 yıla kadar & 44 & 1,6389 & 68078 & & \\
\hline & 4 yıldan 8 yıla kadar & 38 & 1,3129 & ,92236 & & \\
\hline & 8 yıldan 12 yıla kadar & 18 & 1,6358 & ,58770 & & \\
\hline & 12 yıl ve üstü & 14 & 1,4683 & ,93693 & & \\
\hline \multirow{5}{*}{ Duyarsızlaşma } & 2 yıldan az & 13 & 1,8308 & 28102 & \multirow{5}{*}{1,417} & \multirow{5}{*}{0,232} \\
\hline & 2 yıldan 4 yıla kadar & 44 & 1,5864 & 72868 & & \\
\hline & 4 yıldan 8 yıla kadar & 38 & 1,3737 & 99639 & & \\
\hline & 8 yıldan 12 yıla kadar & 18 & 1,8667 & ,98936 & & \\
\hline & 12 yıl ve üstü & 14 & 1,6000 & 73589 & & \\
\hline \multirow{5}{*}{ Kişisel başarı } & 2 yıldan az & 13 & 1,8269 & ,43162 & \multirow{5}{*}{2,771} & \multirow{5}{*}{0,030} \\
\hline & 2 yıldan 4 yıla kadar & 44 & 2,0682 & 61678 & & \\
\hline & 4 yıldan 8 yıla kadar & 38 & 2,0296 & 87930 & & \\
\hline & 8 yıldan 12 yıla kadar & 18 & 1,7569 & ,56307 & & \\
\hline & 12 yıl ve üstü & 14 & 2,5268 & 71921 & & \\
\hline
\end{tabular}

\section{SONUÇ VE ÖNERİLER}

Kars İlinde 127 aşçı üzerinde yapılan çalışma sonucunda aş̧̧ların stres altında ve haftalık izin problemi yaşadığı tespit edilmiştir. Buradan hareket ile anlaşılacağı üzere aşçllık mesleği tükenmişlik sendromunun yaşanmasına müsait bir meslek grubudur. Araştırmaya katılan aşçların 4 üzerinden ortalamasının duygusal tükenme alt boyutunda ( $\bar{x}: 1.54)$, duyarsızlaşma alt boyutunda $(\bar{x}: 1,59)$ ve kişisel başarı alt boyutunda $(\bar{x}: 2,04)$ olduğu belirlenmiştir. Araştırma sonucunda elde edilen ortalama veriler ışığında aşçıların düşük seviyede tükenmişlik düzeyine sahip bir meslek olduğu belirlenmiştir.

Aşçıların cinsiyet, medeni durum ve eğitim durumu ile tükenmişlik düzeyi arasında anlamlı bir farklılık tespit edilememiştir. Literatürde benzer çalışmalarda (Budak ve Sürgevil (2005), Cemaloğlu ve Erdemoğlu Şahin (2007), Gündüz ve arkadaşları (2007), Ardınç ve Polatcı (2008), Pelit ve Türkmen (2008), Özgül ve Atan (2016), Aknar ve arkadaşları (2018), Yenihan ve arkadaşları (2018) ile Doğan ve Akandere (2019)) aynı sonuçların elde edildiği görülmüştür.

Araştırmaya katılan aşçların yaşa göre duyarsızlaşma boyutunda 20 yaş ve altında, 21-30 yaş arasında duyarsızlaşmanın yüksek olduğu, 31-40 yaş arasında ve 41-50 yaş arasında duyarsızlaşmanın azaldığı, 51 yaş ve üzerinde duyarsızlaşmanın en yüksek seviyeye ulaştığı görülmektedir. Kişilerin yaşlarının 30'un altında olduğu dönemlerde kişilerin sorumluluklarının az olması, evlilik ve bakmakla hükümlü oldukları kişilerin bulunmaması, yaşlarına uygun başka işlere geçebilme olanaklarının fazla olması sebebiyle daha duyarsız oldukları görülmüştür. 31 ile 
50 yaşları arasında ise kişinin çocuklarının okula başlaması, sorumluluklarının artması, kişinin olgunlaşması, iş yerinde belli bir tecrübeye ve kıdeme sahip olması nedeniyle işi daha çok sahiplendiği ve duyarsızlığın azaldığı tespit edilmiştir. 51 yaşın üzerinde bulunan kişilerin fiziksel yeteneklerinin azalması, ciddi sağlık sıkıntıları ile karşılaşmaları ve emeklilik hazırlığı yapmaları nedeniyle daha duyarsız hale geldikleri belirlenmiştir. Aknar ve arkadaşları (2018: 89) tarafından turizm çalışanları üzerinde yapılan çalışma sonucunda da benzer bulgular tespit edilmiştir. Sinat ve Kutlu (2009: 179) tarafından ise çalışma verilerinden farklı olarak psikiyatri kliniklerinde çalışan hemşireler üzerinde yaş arttıkça duyarsızlaşmanın azaldığı belirlenmiştir. Buradan anlaşılacağı üzere meslek gruplarına göre tükenmişlik davranışında farklılıklar görülmektedir.

Kişisel başarı yönünde maaşı 4.000 liranın altında olan bireylerin kişisel başarı isteğinin daha fazla olduğu 4.001 ile 5.000 düzeyde maaş alanların ise kişisel başarı isteğinin diğer gruplara göre az olduğu, maaşı 5.000 liranın üzerinde bulunan personelin kişisel başarı isteğinin daha fazla olduğu belirlenmiştir. Kişilerin maaşının artması için daha çok emek harcadığı, maaşı çok olanların ise şükran duygusu ile daha fazla çaba harcadığı belirlenmiştir. Metin ve Gök Özer (2007: 62) tarafından da benzer bulgular tespit edilmiştir. Birçok çalışmada ise ücretin önemli bir unsur olduğu belirtilmiş ise de araştırmaya dâhil edilmediği tespit edilmiştir. Bunun sebebinin aynı görevi yapan akademisyen, polis, hemşire ve diğer görevlilerin birbirine yakın maaşlar alması ve kıdeme göre aralarında önemsiz farkların bulunması sebebiyle olduğu görülmüştür. Polis ve hemşirelerden farklı olarak aşçların bilgi ve becerilerinin artmasına paralel olarak maaşlarında da yüksek oranda artışlar olmaktadır. Kars'ta çalışan aş̧̧lardan Çin, İtalyan ve diğer dünya mutfakları açısından kendisini geliştirenlerin diğer aşçlara göre daha fazla ücret aldığ belirlenmiştir. Aşçların kendi gelişimlerine katkı sağlayacak programlara katılmaları sayesinde ücretlerinde artış yaşanacaktır. Yiyecek ve içecek hizmetlerinin sunulduğu yerlerde ürünlerin kalitesinin yanında besinlerin hazırlanması ve servisinde görevli olan personelin eğitimli ve bilgili olması hem hizmet verilen yerin kalitesi ve sürekliliği hem de imajı açısından çok önemlidir (Spain, 2000:34). Aşçıların aldığı eğitimler sonucunda elde edilen yeni bilgiler ile çalışılan işletmelerin menülerinde yemek ve lezzet çeşitliliği sağlanarak, çalışılan işletmeye rakiplere karşı rekabet avantajı sağlanılacaktır.

Çalışmada deneyim düzeyinde 8 yıldan 12 yıla kadar deneyime sahip grup ile 12 yıl ve üstünde deneyime sahip grup arasında anlamlı bir farklılığın bulunduğu belirlenmiştir. Farklılığın sebebinin kişinin yaşının artması ile beraber çevresinde bulunan yaşıtı kişilerin yavaş yavaş makam ve mevki sahibi olmasının bir yansıması olduğu görülmektedir. Halk arasında Ayşe'nin oğlu doktor olmuş, Ali'nin kızı müdür olmuş gibi söylemlere sık rastlanılmakta ve kişilerin yaşayışını bu söylemler etkilemektedir. Ayrıca kişilerin yaşının artması ile beraber başka sektörde çalışma olanakları azalmakta olup çalıştıkları alanlarda başarı gösterme istekleri artmaktadır. Başarının artırılması açısından kişilerin kendi gelişimlerine katkı sağlayacak eğitim, kurs, seminer ve toplantılara katılması önemlidir. Özellikle ülkemizde de düzenlenen Michelin Yıldızlı Şeflerinde yer aldığı eğitim programlarına katılım aş̧̧ıların mesleki saygınlık ve gelişimi açısından büyük bir fırsat yaratmaktadır.

Çalışmanın Kars İli ile sınırlı olması ve literatürde başka bir çalışmaya rastlanılmaması sebebiyle başka şehirlerde çalışmanın tekrarlanmasının aşçıların tükenmişlik düzeyinin tespitine farklı bir boyut ve bakış açısı sağlayacağı düşünülmektedir. Ayrıca aşçılar üzerinde çalışma yapacak araştırmacılara tükenmişlik ile beraber örgütsel bağlllık, örgütsel sinizm, sosyal ve sanal kaytarma ile çeşitli liderlik modellerinin etkileri ve ilişkileri üzerine çalışılmaları önerilmektedir. 


\section{KAYNAKÇA}

Aknar, A., Çiçek, B. ve Karakaş, Y. (2018). Çalışanların Demografik Özellikleri Açısından Tükenmişlik Algıları: Belek'teki 5 Yıldızlı Oteller Üzerine Bir Araştırma, International Journal of Management and Administration, 2 (3): 1-16. DOI: http://dx.doi.org/10.29064/ijma.351897

Alpar, R. (2013). Uygulamalı Çok Değişkenli İstatistik Yöntemle. (4.Basım), Ankara: Detay Yayıncllık.

Ardınç, K. ve Polatcı, S. (2008). Tükenmişlik Sendromu Akademisyenler Üzerinde Bir Uygulama (GOÜ örneği), Gazi Üniversitesi İktisadi ve İdari Bilimler Fakültesi Dergisi, 10(2): 69-96.

Aslan, Z. ve Etyemez, S. (2015). İşgörenlerin Tükenmişlik Düzeylerinin İşten Ayrılma Niyeti Üzerine Etkisi: Hatay'daki Otel İşletmelerinde Bir Araştırma, İşletme Araştırmaları Dergisi, 7(3): 482-507.

Avşaroğlu, S., Deniz, M.E. ve Kahraman, A. (2005). Teknik Öğretmenlerde Yasam Doyumu İş Doyumu ve Mesleki Tükenmişlik Düzeylerinin İncelenmesi, Selçuk Üniversitesi Sosyal Bilimler Enstitüsü Dergisi, 14:115-129.

Budak, G. ve Sürgevil, O. (2005). Tükenmişlik ve Tükenmişliği Etkileyen Örgütsel Faktörlerin Analizine İlişkin Akademik Personel Üzerinde Bir Uygulama, D.E.Ü. İ.̇.B.F. Dergisi, 20(2): 95-108.

Carson, K.D., Carson, P.P., Roe, C.W., Birkenmeir, B.J. and Phillips, J.S. (1999). Four Commitment Profiles and Their Relationships to Empowerment, Service Recovery, and Work Attitudes, Public Personnel Management, 28(1): 1-13.

Cemaloğlu, N. ve Erdemoğlu Şahin, D. (2007). Öğretmenlerin Mesleki Tükenmişlik Düzeylerinin Farklı Değişkenlere Göre İncelenmesi, Kastamonu Eğitim Dergisi, 15: 465-484.

Cherniss, C. (1980). Staff Burnout, Job Stress in the Human Service. California: Sage Publications.

Cordes, C.L. and Dougherty, T.W. (1993). A Review and An Integration of Research on Job Burnout, Academy of Management Review, 18 (4): 621-656.

Çetin, İ. (2017). Otel Çalışanlarında Tükenmişlik ve Tükenmişliğe Etki Eden Faktörler, Balkan ve Yakın Doğu Sosyal Bilimler Dergisi, 3(2): 83-95.

Denis, D.J. (2019). SPSS Data Analysis for Univariate, Bivariate, and Multivariate Statistics. New Jersey: John Wiley \& Sons, Inc.

Doğan, M. ve Akandere, M. (2019). Taekwondo Antrenörlerinin İş Doyumu ve Tükenmişlik Düzeylerinin İncelenmesi, SPORMETRE Beden Ĕ̆itimi ve Spor Bilimleri Dergisi, 17 (2): 154-162.

Edelwich, J. and Brodsky, A. (1980). Burn-Out-Stages of Disillusionment in the Helping Professions. New York: Human Sciences Press

Ergin, C. (1992). Doktor ve Hemşirelerde Tükenmişlik ve Maslach Tükenmişlik Ölçeğinin Uyarlanması. VII. Ulusal Psikoloji Kongresi Bilimsel Çalışmaları, 22-25 Eylül 1992, Ankara.

Freudenberger, H.J. (1974). Staff Burnout, Journal of Social Issue, 30: 159-165.

Gastronomi Turizmi Derneği, (2018). http://www.gastronomiturizmidernegi.com.tr/ [Erişim Tarihi: 02.08.2019].

Golembiewski, R.T., Munzenrider, R.F. and Carter, D. (1983). Phases of Progressive Burnout and Their Worksite Covariants, Journal of Applied Behavioral Science, 19: 461-481.

Gündüz, Y., Erkan, Y. ve Gökçakan, Y. (2007). Polislerde Tükenmişlik ve Görülen Psikolojik Belirtiler, Çukurova Üniversitesi Sosyal Bilimler Enstitüsü Dergisi, 16 (2): 283-298. 
Güllüce, A.Ç. ve İşçan, F.Ö. (2010). Mesleki Tükenmişlik ve Duygusal Zekâ Arasındaki İlişki, Eskişehir Osmangazi Üniversitesi İ̈BF Dergisi, 5(2): 7-30.

Güven, Ö.Z. ve Sezici, E. (2016). Otel İşletmelerinde İşgörenlerin Tükenmişlik Düzeylerinin Maslach Tükenmişlik Modeline Göre İncelenmesi, Yönetim ve Ekonomi Araştırmaları Dergisi. 14(2): 111-132. DOI: http://dx.doi.org/10.11611/JMER825

Hackman, J.R. and Oldham, G.R. (1975). Development of the Job Diagnostic Survey, Journal of Applied Psychology, 60 (2): 159-170.

Hair, J., Anderson, E.R., Tahtam, L.R. and Black, C.W. (2014). Multivariate Data Analysis. (7. Basım), Essex: Pearson Education Limited.

Harbalığlu, M. ve Ünal, İ. (2014). Aşçılık Programı Öğrencilerinin Mesleki Tutumlarının Belirlenmesi: Ön Lisans Düzeyinde Bir Uygulama, Turizm Akademik Dergisi, 1 (1): 55-65.

Horng, J.S. and Hu, M.L. (2008). The Mystery in the Kitchen: Culinary Creativity. Creativity Research Journal, 20(2): 221-230.

Hughes, M. H. (2003). Culinary Professional Training: Measurement of Nutrition Knowledge Among Culinary Students Enrolled in a Southeastern Culinary Arts Institute, Unpublished Doctoral Dissertation, Alabama University, Alabama.

Kaplan, M. ve Ulutaş, Ö. (2016). Duygusal Emeğin Tükenmişlik Üzerindeki Etkisi: Otel İşletmelerinde Bir Araştırma, Selçuk Üniversitesi Sosyal Bilimler Enstitüsü Dergisi, 35: 165-174.

Kayan Fadlelmula, F. (2015). Akademisyenlerin Tükenmişlik Düzeyleri, Ondokuz Mayıs Üniversitesi Ĕ̆itim Fakültesi Dergisi, 33 (2): 424-438.

Kemer, E. (2019). Otel İşletmeleri İşgörenlerinin Mutluluk Algıları Üzerine Nitel Bir Çalışma, Türk Turizm Araştırmaları Dergisi, 3(3): 283-293. DOI: http://dx.doi.org/10.26677/TR1010.2019.161

Kurnaz, A. (2019). Üniversite Seçimini Etkileyen Faktörler: Aşçllı ve Gastronomi Öğrencileri Üzerine Bir Araştırma, MANAS Sosyal Araştırmalar Dergisi, 8 (1): 612-627. DOI: http://dx.doi.org/10.33206/mjss.479737

Kurnaz, A., Kurnaz, H.A. ve Kılıç, B. (2014). Önlisans Düzeyinde Eğitim Alan Aşçllık Programı Öğrencilerinin Mesleki Tutumlarının Belirlenmesi, Muğla Sıtkı Koçman Üniversitesi Sosyal Bilimler Enstitüsü Dergisi, 32: 41-61.

Maslach, C., Schaufeli, W.B. and Leiter, M.P. (2001). Job Burnout, Annual Review Psychology, 52: 397-422.

Maslach C. and Jacskon S.E. (1981). The Measurement of Experienced Burnout, Journal of Occupational Behaviour, 2: 99-113.

Meier, S.T. (1983). Toward A Theory of Burnout, Human Relations, 36(10): 899-910.

Metin, Ö. ve Gök Özer, F. (2010). Hemşirelerin Tükenmişlik Düzeyinin Belirlenmesi, Anadolu Hemşirelik ve Sağlık Bilimleri Dergisi, 10 (1): 58-66.

$\mathrm{Na}$, E., Kim, H. and Yung, H. (2009). The Relationship Analysis between Job Stress and Turnover Intention of School Foodservice Employees, Korean J. Food Cookery SCI., 25(5): 575-585.

Özgül, F. ve Atan, T. (2016). Öğretmenlerinin Tükenmişlik Düzeylerinin İncelenmesi, Erzincan Üniversitesi Ĕ̆itim Fakültesi Dergisi, 18 (2): 1002-1016. DOI: http://dx.doi.org/10.17556/jef.16981 
Pala T. ve Tepeci M. (2009). Turizm İşletmelerinde Çalışanların Duygusal Emek Düzeyi ve Duygusal Emeğin Çalışanların Tutumlarına Etkileri, 17. Ulusal Yönetim ve Organizasyon Kongresi, 21 - 23 Mayıs 2009, Eskişehir.

Pearlman, B. and Hartman E.A. (1982). Burnout: Summary and Future Research, Human Relations, 35: 283-305.

Pelit, E. ve Türkmen, F. (2008). Otel İşletmeleri İşgörenlerinin Tükenmişlik Düzeyleri: Yerli ve Yabancı Zincir Otel İşletmeleri İşgörenleri Üzerinde Bir Araştırma, Gazi Üniversitesi İktisadi ve İdari Bilimler Fakültesi Dergisi, 10 (1): 117-139.

Serin Karacaer, S. ve Öztürk, Y. (2019). Turizm Değer Zinciri Analizi Üzerine Kavramsal Bir Çerçeve, Türk Turizm Araştırmaları Dergisi, 3(3): 245-260. DOI: http://dx.doi.org/10.26677/TR1010.2019.158

Sinat, O. ve Kutlu, O. (2014). Psikiyatri Kliniklerinde Çalışan Hemşirelerde Tükenmişlik, Florence Nightingale Journal of Nursing, 17 (3): 174-183.

Spain, V.K. (2000). Staff Training Can Add Flavor to Your Menu: Designing an in-House Training Program for Your Kitchen Staff, Camping Magazine, January/February 2000

Survey System (2019). https://www.surveysystem.com/sscalc.htm [Erişim Tarihi: 02.08.2019].

Şad, B. ve Şahin, S. (2018). Otel Çalışanlarının Tükenmişlik Düzeyinin Yaşam Doyumuna Etkisi, Seyahat ve Otel İşletmeciliği Dergisi, 15 (2): 461-480.

Uğuz Çelik, S. (2013). Sürdürülebilir Turizm Kapsamında Burhaniye'nin Alternatif Turizm Potansiyeli, Marmara Coğrafya Dergisi, 24: 332-353.

Ulusoy, H., Biçer, E.B. ve Karabulut, N. (2012). Hastane Yöneticilerinde Tükenmişlik Düzeyi, Cumhuriyet Tip Dergisi, 34: 252-259.

Üngüren, E., Doğan, H., Özmen, M. ve Tekin, Ö.A. (2010). Otel Çalışanlarının Tükenmişlik ve İş Tatmin Düzeyleri İlişkisi, Journal of Yasar University, 17(5): 2922-2937.

Türkiye İstatistik Kurumu (TÜIK)

http://www.tuik.gov.tr/UstMenu.do?metod=temelist[Erişim Tarihi: 02.08.2019].

(2019).

Yenihan, B., Çakır, N.N. ve Alabaşoğlu, B. (2018). Cinsiyet Farklılığın Tükenmişlik ve Yaşam Doyumuna Etkisi: Kırklareli Üniversitesinde Görev Yapan Araştırma Görevlileri Üzerine Bir Araştırma, Kırklareli Üniversitesi İktisadi ve İdari Bilimleri Fakültesi Dergisi, 7(1): 47-56.

Yıldırım, F. (2018). Tükenmişlik Düzeyinin Sanal Kaytarma Davranışına Etkisinde İş Doyumunun Aracılık Rolü, Gazi Üniversitesi Sosyal Bilimler Dergisi, 5 (13): 302-313.

Yüksek Öğretim Kurumu (YÖK) Atlas (2018a). https://yokatlas.yok.gov.tr/mesleklisans.php?b=19024[Erişim Tarihi: 02.08.2019].

Yüksek Öğretim Kurumu (YÖK) Atlas (2018b). https://yokatlas.yok.gov.tr/meslekonlisans.php? $b=30002 \#$ cmeslek_10_onlisans[Erişim Tarihi: 02.08.2019]. 